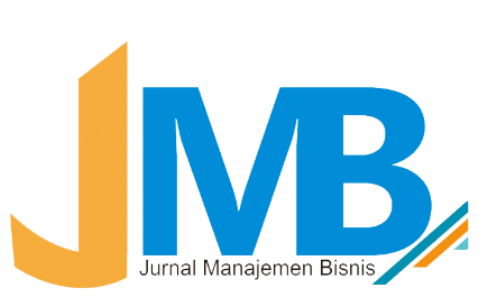

\title{
How Does a University of Choice Come to Students' Mind? From the Aspect of the E-Servicescape of University's Website
}

Kardina Yudha Parwati

Management Department. Universitas Muhammadiyah Malang, East Java, Indonesia

Corresponding Author's Email: kardinayp@umm.ac.id

Received:19-04-2020 | Revision: 11-07-2020| Accepted:15-07-2020

To cite this document:

Parwati, Kardina Y., (2020) "How Does a University of Choice Come to Students' Mind? From the Aspect of the E-Servicescape of University's Website", Manajemen Bisnis, Vol. 10, No. 01, pp.90-99, http://ejournal.umm.ac.id/index.php/imb/article/view/13892

\section{ABSTRACT}

The goals of this study are want to explore the effect of the e-servicescape on private university's website towards student's intention to use the service. This study also wants to know about how does the effect of the e-servicescape towards perceived private university's service quality, and how does the perceived private university's service quality effect towards student's intention to use that service. This study is explanatory research which is using a quantitative approach. A survey using a questionnaire was conducted to collect the data. Moreover, the data of this study was measure in 5 rates Likert's scale and then analyzed using Partial Least Square Method with SmartPLS3 software. The population of this study are the students of a private university in Indonesia. The sample of this study is 165 students of a private university in Indonesia. Purposive sampling technique is used by criteria as follow, the respondent must be private university students and have been seen and looking about their university's website when still school leavers back then. The result of this study is that there is a significant influence of the eservicescape to the perceived service quality. Furthermore, perceived service quality also found to have a significant influence on the student's intention to use the private university service. This study also found that e-servicescape only is not enough to influence the student's intention to use the private university service, and must be mediated by perceived service quality.

Keywords: e-servicescape; perceived quality; intention to use service; university's website

\section{INTRODUCTION}

Higher education becomes one of the most favourable paths for students who graduate from senior high school. People nowadays still have a perception that having a bachelor's degree will open more opportunities to get a job and a promising career. Besides that, people still have thought of joining higher education to gain specified knowledge and competency that they want to use to pursue their careers in the future. The 
rise of the young generation population and the rise of awareness of the importance of having an excellent formal education become the reason why does the number of private universities in Indonesia grows significantly. Based on Kementrian Riset, Teknologi dan Pendidikan in 2017, there are only 3154 private higher educations in Indonesia. Now in 2020, the number of private higher educations in Indonesia increase become 4243 (Kementrian Riset, Teknologi dan Pendidikan, 2020).

The number above shows that private university's struggle to keep its service runs has become more challenging. The private university must put so much effort into giving their students the most excellent academic and administrative service to keep them. A private university's management is different from a public university in terms of its funding resource. The public university gets its government funding while the private university gets its primary funding from its students. A private university must have a strategy to get a student in the middle of the tight competition. The strategy commonly used is by building an excellent perceived quality of service in the head of the school leavers so that they will have an intention to choose it as their university. In this digital era, private universities use digital platforms to communicate their students' values, such as a website. A private university's website is a virtual environment that usually described as an e-servicescape.

In service providers such as educational institutions, e-servicescape is highly pertinent because it offers students various possibilities to preview their services before visiting the actual location. Based on the environmental psychology theory about Stimulus-Organism- Response paradigm (S-O-R) we can rationalize that the online environments will influence people to affect and cognition and then will influence their behaviour (Arbanel, 2013). A well-designed university's website may provide the school leavers or their parents with positive perceptions of the service quality before visiting the university (Seonjeong \& Miyoung, 2012). Service activities cannot be separated between customer and service provider. So it is necessary to develop a physical environment (in this study is the e-servicescape) in which the service is conducted that can influence the perception of the user towards its perceived quality (Wall \& Berry, 2007). Having a good website will give consumers positive experience because the functional aspects (adequacy of information, navigation structure, interactive) are the essential feature of eservicescape when clients want to get in-depth information about the company, facilities, and list of services (Hakim \& Deswindi, 2015).

E-servicescape needs to be managed to create the website's positive perceived service quality that can result in customer intention to use the service (Tankovic, Benazic, \& Tankovic, 2018). When the student leavers or parents that have a look at the university's website (stimulus), they will experience the physical environment of the website and store some information about the university. That can influence their cognitive and affect. After that, they will be a judge the quality of the academic service by that experience and information (organism). The favourable judgement of the student leavers or parents will lead to student's intention to use the service of the private university. 
Based on the phenomena that explained in the past paragraph, so this paper aims to want to explore the effect of the e-servicescape towards student's intention to use a private university service. This study also wants to know about how does the effect of the e-servicescape towards perceived private university's service quality, and how does the perceived private university's service quality effect towards student's intention to use a private university service. This paper seeks the relationship among those variables in the educational institution because there still no study assessing the importance of eservicescape in this field in the previous study.

\section{LITERATURE REVIEW}

A servicescape defines the physical existence of an entity, including design, layout, decoration, and aesthetics. In an online environment, the dimension of servicescape adopted into the digital aspect, and the term become e-servicescape (Koering, 2003). Some previous study also states that the physical environment, such as e-servicescape can generate the customer intention to buy a product/ or use a service. Chaeyeon \& Eunjoo (2013) on his study found that there were three dimensions of eservicescapes viewed by fashion consumers: (1) visual appeal, (2) environmental factors, and (3) layout \& functionality. These e-servicescape dimensions affected consumers to push positive emotions and purchasing intentions on a fashion e-commerce website. A study of Hopkins, Grove, Raymond, \& Laforge (2009) also found that website design of online ticketing has a positive influence on customer's intention to buy. Harris \& Goode (2010) study also found that e-servicescape can influence the customer's purchase intention because the good aesthetic appeal, layout, functionality, and financial security can generate the trust in the website and then lead to the purchase intention. The same result also found on the study of Huang, Li, \& Mou (2017), e-servicescape of hotel website has a positive influence on customer intention to book.

Based on the environmental psychology theory about Stimulus-OrganismResponse paradigm (S-O-R) we can rationalize that the online environments will influence people to affect and cognition and then will influence their behaviour (Arbanel, 2013). The positive cognition and effect mentioned above can generate a positive perceived service quality in the consumer's mind. That statement was empirically proven by Hakim \& Deswindi (2015) that ambient condition, design aspects, aid and slogans, and functional aspects of e-servicescapes hospital website could influence a positive perceived service quality of hospital in customer or service user's mind. A study of Hopkins, Grove, Raymond, \& Laforge (2009) also found that website design of online ticketing has a positive influence on customer's upbeat assessment and attitude to the website.

Positive perceived service quality as an organism in the S-O-R paradigm will also lead a positive customer response. A consumer that has a good perception of a product or service quality will tend to buy or use that product or service. This statement is supported empirically by some studies like Hakim \& Deswindi (2015). Their study found that perceived quality influences customer intention to use a hospital service. Another study 
of Tankovic et al. (2018) found that e-shopping quality which affects attitudinal loyalty or customer's intention to repurchase. A study of Wu, Phu, Quyen, \& Rivas (2016) also found that customer attitude to the website has a positive effect on the purchase intention.

Based on the literature review and the previous studies about e-servicescape, perceived service quality, and intention to use, so the hypotheses that proposed in this study are H1. E-servicescape of private university website influences student's intention to use the private university service. H2. E-servicescape of private university website influences the perceived service quality of the university. H3. Perceived service quality influences the student's intention to use the service. H4. Perceived service quality could mediate the influence of the e-servicescape toward the student's intention to use the private university service. The research framework of this study, as seen in Figure 1.

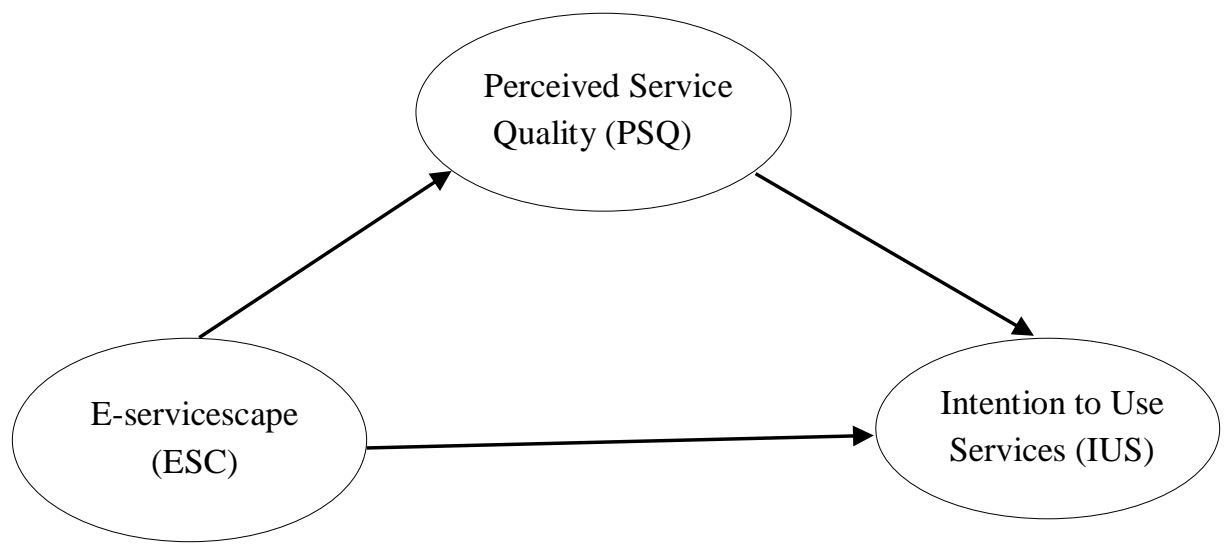

Figure 1. Research Framework

\section{RESEARCH METHOD}

This study is explanatory research because this study wants to know the relationship between e-servicescape, perceived service quality, and intention to use. This study using a quantitative approach to conducting a survey using a questionnaire. The population of this study are the students of a private university in Indonesia. The sample of this study is 165 students of a private university in Indonesia. The amount of sample chooses based on the calculation the effect size of the sample by using G-Power software. This study using nonprobability sampling method because there is no exact amount of Indonesia private students. Moreover, the purposive sampling technique is used by criteria as follow, the respondent must be private university students and have been seen and looking about their university's website when still school leavers back then. So the data that gathered in this study is primary and cross-section data. The data of this study was measure in 5 rates Likert's scale and then analyzed using Partial Least Square Method with SmartPLS3 software. The measurement of e-servicescape variable is adapted from the indicator proposed by Hakim \& Deswindi (2015) namely ambient conditions, design aspects, search aids and slogans, functional aspects. Measurement for perceived service 
variable adapted from the study of Jeon and Jeong (2009) using cognitive response, emotional response, and phsycological response. For the intention to use the service this study adopted from Huang, Li, \& Mou (2017) study.

\section{RESULT AND DISCUSSION}

The collected data in this study then analyzed using Partial Least Square Method with SmartPLS3 software. In Partial Least Square Method, there is a two type of measurement, the first is the measurement of the outer model, and the second is the inner model. The outer is used to know the value of convergent validity, discriminant validity, and composite reliability. Table 1 is the result of convergent validity. Convergent validity used to test the validity of each item of the variables in the questionnaire. The criteria of this test are the outer loading coefficient, or the loading factors of each item must be greater or equal than 0.700 (Hair, Hopkins, \& Kuppelwieser, 2014).

Table 1. Validity Test

\begin{tabular}{ccccc}
\hline & Outer Loading & $\begin{array}{c}\text { Standard } \\
\text { Deviation }(\text { STDEV })\end{array}$ & $\begin{array}{c}\text { T Statistics } \\
(\mid \text { O/STERR } \mid)\end{array}$ & p-value \\
\hline ESC11 <- ESC & 0.767 & 0.032 & 19.752 & 0.000 \\
ESC12 <- ESC & 0.814 & 0.034 & 22.697 & 0.000 \\
ESC13 <- ESC & 0.822 & 0.035 & 24.302 & 0.000 \\
ESC21 <- ESC & 0.802 & 0.032 & 23.321 & 0.000 \\
ESC22 <- ESC & 0.710 & 0.051 & 12.514 & 0.000 \\
ESC31 <- ESC & 0.862 & 0.027 & 39.191 & 0.000 \\
ESC32 <- ESC & 0.773 & 0.036 & 22.627 & 0.000 \\
ESC41 <- ESC & 0.774 & 0.039 & 20.675 & 0.000 \\
ESC42 <- ESC & 0.732 & 0.041 & 17.563 & 0.000 \\
PSQ11 <- PSQ & 0.728 & 0.044 & 16.607 & 0.000 \\
PSQ12 <- PSQ & 0.721 & 0.043 & 15.682 & 0.000 \\
PSQ21 <- PSQ & 0.736 & 0.052 & 13.238 & 0.000 \\
PSQ22 <- PSQ & 0.741 & 0.067 & 10.887 & 0.000 \\
PSQ31 <- PSQ & 0.752 & 0.049 & 15.106 & 0.000 \\
PSQ32 <- PSQ & 0.763 & 0.043 & 18.668 & 0.000 \\
IUS1 <- IUS & 0.832 & 0.042 & 20.053 & 0.000 \\
IUS2 <- IUS & 0.856 & 0.021 & 36.386 & 0.000 \\
IUS3 <- IUS & 0.717 & 0.052 & 13.729 & 0.000 \\
\hline
\end{tabular}

From Table 1. can be inferred that each variable's item in this study has a value greater than 0.700 so that all items in the questionnaire is valid.

The second test is discriminant validity. This test used to make sure that all items that used to measure a variable can predict better than other variables in the model. The criteria of discriminant validity test are the score of the cross-loading of a variable's items must be greater than the cross-loading of the other variables in the model. (Hair et al., 2014). The result of this study discriminant validity test can be seen on the Table 2 . 
How Does a University of Choice Come to Students' Mind?

From the Aspect of the E-Servicescape of University's Website

Table 2. Discriminant Validity (Cross Loading)

\begin{tabular}{cccc}
\hline & ESC & PSQ & IUS \\
\hline ESC11 & $\mathbf{0 . 7 7 7}$ & 0.451 & 0.667 \\
ESC12 & $\mathbf{0 . 7 1 5}$ & 0.535 & 0.522 \\
ESC13 & $\mathbf{0 . 8 1 8}$ & 0.443 & 0.546 \\
ESC21 & $\mathbf{0 . 8 2 3}$ & 0.472 & 0.602 \\
ESC22 & $\mathbf{0 . 7 6 0}$ & 0.362 & 0.432 \\
ESC31 & $\mathbf{0 . 7 2 3}$ & 0.461 & 0.532 \\
ESC32 & $\mathbf{0 . 7 2 5}$ & 0.375 & 0.402 \\
ESC41 & $\mathbf{0 . 8 6 1}$ & 0.452 & 0.592 \\
ESC42 & $\mathbf{0 . 7 2 2}$ & 0.343 & 0.464 \\
PSQ11 & 0.443 & $\mathbf{0 . 7 2 1}$ & 0.411 \\
PSQ12 & 0.467 & $\mathbf{0 . 7 3 4}$ & 0.401 \\
PSQ21 & 0.432 & $\mathbf{0 . 7 2 7}$ & 0.279 \\
PSQ22 & 0.372 & $\mathbf{0 . 7 2 6}$ & 0.344 \\
PSQ31 & 0.451 & $\mathbf{0 . 7 4 2}$ & 0.421 \\
PSQ32 & 0.362 & $\mathbf{0 . 7 3 2}$ & 0.432 \\
IUS1 & 0.528 & 0.455 & $\mathbf{0 . 8 2 1}$ \\
IUS2 & 0.534 & 0.453 & $\mathbf{0 . 8 3 1}$ \\
IUS3 & 0.519 & 0.518 & $\mathbf{0 . 7 2 4}$ \\
\hline
\end{tabular}

From Table 2. It can be seen that the score of the cross-loading of the e-servicescapes items is greater than the cross-loading of the other variables in the model, and also or the perceived service quality items and intention to use the service items. So that all the items in this study have a good discriminant validity.

The third test is the reliability test of the latent variables. An instrument is reliable when it has composite reliability and Cronbach Alpha's value are greater or equal than 0.700. And the value AVE must be greater or equal than 0.500 (Hair et al., 2014). From Table 3, it can be seen that the composite reliability, Cronbach Alpha's, and AVE for eservicescapes, perceived service quality, and intention to use the service have passed those criteria. So the instrument of this study is reliable.

Tabel 3. Reliability Test

\begin{tabular}{cccc}
\hline & AVE & Composite Reliability & Cronbachs Alpha \\
\hline ESC & 0.552 & 0.716 & 0.722 \\
PSQ & 0.621 & 0.813 & 0.711 \\
IUS & 0.607 & 0.757 & 0.734 \\
\hline
\end{tabular}

The next is the inner model measurement. The model in this study has score 0.383 in Goodness of Fit Model test, which its calculation based on the score of perceived service quality and intention to use the service's R2 as follow.

$$
\begin{aligned}
\mathrm{R}^{2} \text { models } & =1-\left(1-\mathrm{R}^{2} 1\right)\left(1-\mathrm{R}^{2} 2\right) \\
& =1-(1-0.223)(1-0.206) \\
& =1-(0.777)(0.794) \\
& =1-0.616=0.383
\end{aligned}
$$


That score means that the diversity of data generated from the structural model examined in this study is $38.3 \%$, and other variables explain the remaining $61.7 \%$ outside of this research model.

To know about the relationship among variables can be seen from the significance of the estimated parameters. The statistical test for hypothesis testing using t-test. If the $\mathrm{t}$-statistic is greater than the t-table, the research hypothesis is accepted. However, if the t-statistic is smaller than the t-table, the research hypothesis will be rejected. In this research, the t-table was 1.96 with alpha 0.05 . The statistical test in PLS is carried out using the bootstrap resampling method, which can minimize the abnormalities of the research data. Table 4 shows the bootstrapping results of the direct effect of the independent variable on the dependent variable. Table 5 shows the results for the indirect effect.

Table 4. Path Coefficient

\begin{tabular}{lccc}
\hline & $\begin{array}{c}\text { Path } \\
\text { Coefficient }\end{array}$ & T Statistics & P - values \\
\hline ESC -> IUS & 0.034 & 0.422 & 0.670 \\
ESC -> PSQ & 0.523 & 7.082 & 0.000 \\
PSQ -> IUS & 0.401 & 5.741 & 0.000 \\
\hline
\end{tabular}

Based on Table 4, the path coefficient of e-servicescape to intention to use service is 0.034 , and the $t$ statistics is 0.422 , smaller than 1.96 . The $p$-value is 0.670 or greater than 0.05 . So that e-servicescape does not have a significant influence on the student's intention to use the private university service. That also means that $\mathrm{H} 1$ is rejected. This result contrary with the research findings of Chaeyeon \& Eunjoo (2013), Hopkins, Grove, Raymond, \& Laforge (2009), Harris \& Goode (2010), Huang, Li, \& Mou (2017) that found e-servicescape can influence the customer's purchase intention or intention to use the service. That might be happening because of the different research object of this study. This might be happening because choosing a university service is a big deal, that can influence their future so that the students will not choose it only based on how does its website. There will be more variables which are influencing the student's intention to use a private university service such as the tuition fee, the university's location, the study programme offered, the competency of the lectures, and the other variables.

As seen in Table 4, the path coefficient of e-servicescape to perceived service quality is 0.523 , and the $t$ statistics is 7.082 , more significant than 1.96 . The p-value is 0.000 or smaller than 0.05 . So that e-servicescape has a significant and positive influence on the student's perceived service quality of the private university. That also means that H2 is accepted. This result supports the research findings by Arbanel (2013), Hakim \& Deswindi (2015), and Hopkins, Grove, Raymond, \& Laforge (2009) Which is find that e-servicescape has a positive and significant influence on perceived service quality. The ambient condition such as good quality photo, animation and, the effect on the website also the classy look website colour can influence can give a signal that the university has good management and professional service. It also can improve the positive image of the university in the student's mind. The design aspects, the interactive part of the website, 
navigation structure, the search aids and slogan aspects of university's website will make students even their parents quickly to get information about the university. Moreover, the university must take this opportunity to share information about their superior things and unique selling point. More positive information received by students may lead to positive perceived service quality of the university.

As seen in Table 4, the path coefficient of perceived service quality to intention to use service is 0.401 , and the $t$ statistics is 5.71, more significant than 1.96 . The p-value is 0.000 or smaller than 0.05 . So that student has perceived service quality of the private university has a significant and positive influence on student's intention to use the private university service. That also means that $\mathrm{H} 3$ is accepted. This result supports the research findings by Hakim \& Deswindi (2015), Tankovic et al. (2018), Wu, Phu, Quyen, \& Rivas (2016) which is find that perceived service quality has a positive and significant influence on customer's intention to buy or use the services. Students that look into the university website will assess the overall perception of the quality of the university based on emotional, cognitive, In the minds of clients. The positive evaluation will influence the behavioural response of the students, such as having the intention to use e the university service.

Table 5. Indirect Effect

\begin{tabular}{lcccc}
\hline & $\begin{array}{c}\text { Original } \\
\text { Sample } \\
(\mathrm{O})\end{array}$ & $\begin{array}{c}\text { Standard } \\
\text { Deviation } \\
(\text { STDEV })\end{array}$ & $\begin{array}{c}\text { T Statistics } \\
(|\mathrm{O} / \mathrm{STDEV}|)\end{array}$ & P VALUES \\
\hline ESC -> PSQ -> IUS & 0.209 & 0.063 & 4.157 & 0.000 \\
\hline
\end{tabular}

Table 5 shows the result of the hypothesis testing of the indirect effect of e-servicescape towards student's intention to use the private university service through perceived service quality. In Table 5 it shows that the $t$ statistic is 4.157 or greater than 1.96 , and the pvalue is 0.000 or smaller than 0.05 . So we can infer that perceived service quality has a vital role in mediating the influence of e-servicescape to intention to use the service, or $\mathrm{H} 4$ is accepted. Furthermore, the path coefficient of the indirect effect is 0.209 which is greater than its direct effect, 0.034 , so that perceived service quality fully mediated the influence of e-servicescape to student's intention to use the private university service.

\section{CONCLUSION}

The result of this are there is a significant influence of the e-servicescape to the perceived service quality. And perceived service quality also found have a significant influence toward the student's intention to use the private university service. This study also found that e-servicescape only is not enough to influence the student's intention to use the private university service, and must be mediated by perceived service quality. From that result, we can infer that still vital for the private university to maintain its website. Because the website is the physical environment where the students meet the service provider and will assess the quality of services based on its ambient condition, 
design aspect, search aid and slogan, also functional aspects. More positive university's perceived service quality in customers mind the will generate the intention of the students to use the service. In other words, the students do not want to choose the wrong path, the wants to assure the service quality of the university by looking and gathered information at the university's website.

E-servicescape is multidimensional construct but in this study e-servicescape measured as a single dimension construct. So the future research can assess the effect of the E-servicescape in second order analysis to get a better and deeper understanding. In this study only seeing the antecedent of the intention to use service by 2 variables. Future research can add other variable that may influence the students' intention to use the service, such as emotion, attitude, and university image.

\section{REFERENCES}

Arbanel, B. L. (2013). Mapping the Online Gambling e-Servicescape : A Conceptual Model. UNLV Gaming Research \& Review Journal, 17(2), 44.

Chaeyeon, L., \& Eunjoo, P. (2013). 구매의도에 미치는 영향 Effects of E-servicescape and Positive Emotion on Purchase Intention for. Korean Journal of Human Ecology, 22(1), 157-166.

Hair, J. F., Hopkins, L., \& Kuppelwieser, V. G. (2014). Partial least squares structural equation modeling ( PLS-SEM) An emerging tool in business research. European Business Review, 26(2), 106-121. https://doi.org/10.1108/EBR-10-2013-0128

Hakim, L., \& Deswindi, L. (2015). Assessing the Effects of e-servicescape on Customer Intention : A Study on the Hospital Websites in South Jakarta. Procedia - Social and Behavioral Sciences, 169(August 2014), 227-239. https://doi.org/10.1016/j.sbspro.2015.01.306

Harris, L. C., \& Goode, M. M. H. (2010). Online servicescapes, trust, and purchase intentions. Journal of Service Marketing, 3(July 2008), 230-243. https://doi.org/10.1108/08876041011040631

Hopkins, C. D., Grove, S. J., Raymond, M. A., \& Laforge, M. C. (2009). Designing the e-Servicescape : Implications for Online Retailers Designing the e-Servicescape : Implications for Online Retailers. Journal o Internet and Commerce, 8 (November 2014), 23-42. https://doi.org/10.1080/15332860903182487

Huang, D., Li, Z., \& Mou, J. (2017). Effects of flow on young Chinese consumers ' purchase intention: a study of e-servicescape in hotel booking context. Information Technology \& Tourism. https://doi.org/10.1007/s40558-016-0073-0

Jeon, Myunghee (Mindy) and Jeong, Miyoung, (2009). A Conceptual Framework to Measure E-Servicescape on a B\&B Website, International CHRIE ConferenceRefereed Track. 14. https://scholarworks.umass.edu/refereed/Sessions/Saturday/14

Kementrian Riset, Teknologi dan Pendidikan. (2020, April 1). Grafik Jumlah Perguruan Tinggi [Web page]. $\quad$ Retrieved from 


\section{https://forlap.ristekdikti.go.id/perguruantinggi/homegraphpt}

Koering, S. (2003), "E-scape: the electronic physical environment and service tangibility", Psychology \& Marketing, Vol. 20 No. 2, pp. 151-67.

Seonjeong, L. (Ally), \& Miyoung, J. (2012). Effects of e-servicescape on consumers' flow experiences", Journal of Hospitality and Tourism Technology. Journal of Hospitality and Tourism Technology, 3(1), 47-59. https://doi.org/10.1108/17579881211206534

Tankovic, A. C., Benazic, D., \& Tankovic, A. C. (2018). and customer loyalty The perception of e-servicescape and its influence on perceived e-shopping value and customer loyalty. Online Information Review. https://doi.org/10.1108/OIR-122016-0354

Wu, W., Phu, T., Quyen, P., \& Rivas, A. A. A. (2016). How e-servicescapes affect customer online shopping intention : the moderating effects of gender and online purchasing experience. Information Systems and E-Business Management, (55). https://doi.org/10.1007/s10257-016-0323-x

Wall, E. A. \& Berry, L. L. (2007). The combined effects of the physical environment and employee behavior on customer perception of restaurant service quality, Cornell Hotel and Restaurant Administration Quarterly, 48(1), 59-69 